\section{(6) OPEN ACCESS}

\title{
Occult blood in faeces is associated with all-cause and non-colorectal cancer mortality
}

\author{
Gillian Libby, ${ }_{1}^{1}$ Callum G Fraser, ${ }^{1}$ Frank A Carey, ${ }^{2}$ David H Brewster, ${ }^{3}$ Robert J C Steele ${ }^{1}$
}

\begin{abstract}
${ }^{1}$ Bowel Screening Research Unit, Centre for Research into Cancer Prevention and Screening, Medical Research Institute, Division of Cancer, Ninewells Hospital and Medical School, Dundee, Scotland ${ }^{2}$ Department of Pathology, Ninewells Hospital and Medical School, Dundee, Scotland, UK ${ }^{3}$ Scottish Cancer Registry, National Services Division Edinburgh, Scotland
\end{abstract}

Correspondence to Professor Robert J C Steele, Division of Cancer, Medical Research Institute, Ninewells Hospital and Medical School Dundee DD19SY, Scotland; r.j.c. steele@dundee.ac.uk

Received 21 March 2018 Revised 27 April 2018 Accepted 7 May 2018 Published Online First 16 July 2018

\section{SLinked}

- http://dx.doi.org/10.1136/ gutjnl-2018-316762

Check for updates

To cite: Libby G, Fraser CG, Carey FA, et al. Gut

2018:67:2116-2123.

\section{ABSTRACT}

Objective An association between detectable faecal haemoglobin $(f-H b)$ and both the risk of death from colorectal cancer (CRC) and all-cause mortality has been reported. We set out to confirm or refute this observation in a UK population and to explore the association between $\mathrm{f}-\mathrm{Hb}$, as indicated by a positive guaiac faecal occult blood test (gFOBT) result, and different causes of death.

Design All individuals (134 192) who participated in gFOBT screening in Tayside, Scotland between 29/03/2000 and 29/03/2016 were studied by linking their test result (positive or negative) with mortality data from the National Records of Scotland database and following to 30/03/2016.

Results Those with a positive test result $(n=2714)$ had a higher risk of dying than those with a negative result, from CRC: HR 7.79 (95\% Cl 6.13 to 9.89), p<0.0001, (adjusted for, gender, age, deprivation quintile and medication that can cause bleeding) and all non-CRC causes: HR $1.58(95 \% \mathrm{Cl} 1.45$ to 1.73$), p<0 \cdot 0001 \cdot \cdot \ln$ addition, $\mathrm{f}-\mathrm{Hb}$ detectable by $\mathrm{gFOBT}$ was significantly associated with increased risk of dying from circulatory disease, respiratory disease, digestive diseases (excluding $(R C)$, neuropsychological disease, blood and endocrine disease and non-CRC.

Conclusion The presence of detectable $\mathrm{f}-\mathrm{Hb}$ is associated with increased risk of death from a wide range of causes.

\section{INTRODUCTION}

Testing for the presence of blood in faeces is widely used for colorectal cancer (CRC) screening and, several years ago, the four constituent countries of the UK established population screening programmes based on the guaiac faecal occult blood test (gFOBT). ${ }^{1}$ A test result positive for blood in faeces confers a high risk of harbouring and perhaps developing either CRC or its precursor lesion, an adenoma $^{23}$ and it follows that an asymptomatic population of individuals with positive gFOBT results have a higher risk of CRC mortality than those who have negative results. In Taiwan, where population screening is conducted using a quantitative faecal immunochemical test (FIT), which employs antibodies against human haemoglobin $(\mathrm{Hb})$ and provides a faecal haemoglobin (f- $\mathrm{Hb}$ ) concentration estimate, an incremental increase in $\mathrm{f}-\mathrm{Hb}$ was observed to be associated with increasing risk of death from CRC. ${ }^{4}$ In addition, however, a similar association with all-cause mortality was

\section{Significance of this study}

What is already known on this subject?

- Testing for the presence of haemoglobin in faeces is widely used for colorectal cancer (CRC) screening.

- Faecal occult blood test (FOBT) positivity, a surrogate marker for the presence of faecal haemoglobin $(\mathrm{f}-\mathrm{Hb})$, is associated with male sex, age and deprivation.

- An incremental increase in $\mathrm{f}-\mathrm{Hb}$ has been observed to be associated with increasing risk of death from CRC and all-cause mortality.

What are the new findings?

- Those with a positive FOBT result had a higher risk of dying from CRC than those with a negative result when adjusted for, gender, age, deprivation and prescription of medicines that can cause bleeding; this association held also for all-cause mortality excluding death from CRC

- After again correcting for gender, age, deprivation and prescription of medicines that can cause bleeding, a positive FOBT result was significantly associated with increased risk of dying from circulatory, respiratory, neuropsychological, blood, endocrine and digestive diseases (excluding (RC) and non-CRCs.

- The presence of $\mathrm{f}-\mathrm{Hb}$ confers increased risk of death from a range of causes in addition to CRC.

observed and this trend persisted after exclusion of all CRC deaths suggesting that the presence of $\mathrm{Hb}$ in faeces could be a predictor of life expectancy independent from its association with CRC. However, the magnitude of the association with non-CRC deaths was not quantified, the non-CRC causes of death were not explored and corrections for gender, age and deprivation, all of which are associated with $\mathrm{f}-\mathrm{Hb},{ }^{5}$ were not made. Furthermore, it was not possible to adjust for the use of medicines that could cause bleeding into the gastrointestinal tract.

In Scotland, gFOBT screening commenced in March 2000 with a demonstration pilot in three of the 14 NHS Boards charged with delivery of healthcare in Scotland on a geographical basis (Grampian, Tayside and Fife) and a matched cohort study comparing these pilot areas with the rest of Scotland 
Significance of this study

\section{How might it impact on clinical practice in the foreseeable future?}

- $\mathrm{f}-\mathrm{Hb}$ might have potential as a modifiable biomarker that could be used to assess the efficacy of both lifestyle and prescribing interventions to reduce the risk of premature mortality and might also be used to explore the underlying reasons for different patterns of mortality in different populations across the world.

- A positive $\mathrm{f}$-Hb could be used to alert those participating in CRC screening to the risk of reversible non-communicable disease, regardless of the presence or absence of colorectal neoplasia.

- These suggestions are currently speculative and require prospective studies using quantitative faecal immunochemical testing (FIT) for haemoglobin before they could be implemented.

demonstrated a $10 \%$ relative reduction in CRC mortality, rising to a $27 \%$ reduction when adjusted for participation. ${ }^{6}$ By linking the pilot screening data and subsequent programme data with the National Records of Scotland database, it was possible to study the association between a positive gFOBT result and both CRC and non-CRC mortality in the Scottish population. In addition, by linking with databases on medicine prescribing, it was possible to study the association between prescribed medicines and gFOBT positivity and to examine the confounding effect of such medicines on the association between gFOBT positivity and cause of death.

\section{METHODS}

\section{Study cohort}

The study cohort consisted of all men and women residing in the NHS Tayside Board area of Scotland, who participated in the Scottish arm of the UK CRC demonstration pilot (March 2000 to September 2007) or the subsequent Scottish Bowel Screening Programme (2007 onwards). The age range for the pilot was 50-69 years and this was extended to 74 years for the Programme. The NHS Tayside Board area was chosen since it is possible to determine the history of community medicine prescribing for all residents registered with a general practitioner (GP). The first screening test result available was used to classify individuals as having either a positive or negative result and they were then followed from the date of this test result to $30 / 03 / 2016$ or date of death if this was earlier. It is possible that some members of the negative cohort may have had a subsequent positive test result, but this could not invalidate the conclusions as it would serve to reduce rather than exaggerate the difference between the negative and positive groups.

For screening participants, a test result, defined as positive or negative, was obtained from the Bowel Screening Scotland (BoSS) database. Individuals were excluded from this study if they had returned their test kit for analysis but a positive or negative result could not be obtained, for example, if a test kit was spoiled. The screening algorithms are detailed elsewhere, ${ }^{78}$ but were all based on an initial gFOBT kit (hema-screen, Immunostics, Ocean, New Jersey, USA) sent by post to complete at home and then returned to the Scottish Bowel Screening Centre Laboratory for analysis.
Table 1 Medicines included in those that 'increase the risk of bleeding' category

\begin{tabular}{ll}
\hline $\begin{array}{l}\text { British National Formulary } \\
\text { Category (http://www.bnf. } \\
\text { org) }\end{array}$ & Medicines \\
\hline 2.8 & All parenteral and oral anticoagulants \\
2.9 & All antiplatelet agents (including aspirin) \\
6.3 & Glucocorticoid therapy \\
10.1 .1 & All non-steroidal anti-inflammatory drugs \\
\hline
\end{tabular}

\section{Medicine prescribing}

Information from the database of community dispensed prescribing was obtained from the Health Informatics Centre (HIC) at the University of Dundee. Two categories of medicines were selected which may have contributed to the presence of blood in faeces: (1) aspirin and (2) all drugs (including aspirin) that increase the risk of bleeding. The list of medicines included in the latter category were derived from the British National Formulary (http://www.bnf.org) and the relevant sections of the Formulary are given in table 1. Prescribing for any of these was included in the analysis if a prescription was dated in the 16 weeks preceding the date of the screening test result. This time period was chosen to capture repeat prescriptions for those people on long-term medication with 2 monthly repeats.

\section{Mortality data}

Screening data were record-linked to mortality data obtained from the National Records of Scotland database and anonymised before analysis. The cause of death used in this study was identified solely from the underlying cause recorded on the death certificate. No account was taken of potential migration from Scotland during the follow-up period and individuals were considered to be alive at 30/03/2016 if no date of death was recorded in the database. Thus, it is possible that some individuals might have died outside Scotland, but this would be a very small number and there is no reason to suppose that the proportion of such deaths would have been different in the test positive and negative groups.

In addition to considering all-cause mortality, the causes of death were recorded using the International Classification of Diseases (ICD 10) codes, ${ }^{9}$ and these were categorised following a format used by Whynes et $a l^{10}$ in a study examining cause of death in the Nottingham randomised trial of gFOBT. Non-cancer causes were defined as deaths from circulatory diseases (code I), respiratory diseases (code J), digestive system diseases (code $\mathrm{K}$ ), neuropsychological conditions (codes F and G), external factors (codes S-Z) and diseases of the blood and endocrine system (codes D and E). Cancers were separated into CRC (code C180-9, C19, C20) and all other cancers (all remaining code C) were categorised as 'other cancer'. Any remaining deaths were categorised as 'other'.

\section{Statistical methods}

Cause-specific mortality rates were compared for the positive and negative test result groups. Person years of follow-up in each group were calculated from the date of the screening test result to $30 / 03 / 2016$ or date of death, if earlier. Mortality rates in each group were calculated as the number of deaths divided by the person years of follow-up. Cumulative mortality rates for all-cause mortality, CRC mortality and non-CRC mortality were plotted by years since the screening test result for the positive and negative groups. 
Table 2 Demographic comparison between those with a negative and positive guaiac faecal occult blood test result

\begin{tabular}{|c|c|c|c|}
\hline & Negative result $(n=131207)$ & Positive result $(n=2714)$ & $\begin{array}{l}\text { Comparison of positive and negative } \\
\text { groups }\end{array}$ \\
\hline & $\mathrm{N}(\%)$ & N (\%) & P value* \\
\hline Females & 69987 (98.5) & $1056(1.5)$ & \\
\hline Males & $61220(97.4)$ & $1658(2.6)$ & $<0.001$ \\
\hline Age at screening (median, IQR) & $54(50-62)$ & $58(52-65)$ & $<0.0001$ \\
\hline \multicolumn{4}{|l|}{ Age group at screening (years) } \\
\hline $50-54$ & $66778(98.5)$ & $992(1.5)$ & \\
\hline $55-59$ & $23242(97.8)$ & $520(2.2)$ & \\
\hline $60-64$ & $19948(97.5)$ & $511(2.5)$ & \\
\hline $65-69$ & $17190(97.0)$ & $526(3.0)$ & \\
\hline $70+$ & 4049 (96.1) & $165(3.9)$ & $<0.0001$ \\
\hline SIMD 1 (most deprived) & $15505(96.8)$ & $514(3.2)$ & \\
\hline 2 & $17169(97.5)$ & $440(2.5)$ & \\
\hline 3 & $23169(97.8)$ & $481(2.0)$ & \\
\hline 4 & $45704(98.2)$ & $819(1.8)$ & \\
\hline 5 (least deprived) & $28790(98.5)$ & $444(1.5)$ & $<0.0001$ \\
\hline \multicolumn{4}{|l|}{ Prescriptions for: } \\
\hline Aspirin & $21540(16.4)$ & $596(21.9)$ & $<0.0001$ \\
\hline \multirow[t]{2}{*}{ Medicines that can cause bleeding $t$} & $24163(18.4)$ & $796(29.3)$ & \\
\hline & & & $<0.0001$ \\
\hline Died (at 31/03/2016) & $12632(9.6)$ & $594(21.9)$ & $<0.0001$ \\
\hline Age died (median, IQR) & $71(65-76)$ & $70(64-75)$ & 0.002 \\
\hline
\end{tabular}

${ }^{*} \chi^{2}$ test or Wilcoxon rank sum test.

tIncludes aspirin.

SMID, Scottish Index of Multiple Deprivation.

Cox regression was used to compare time to all-cause deaths, CRC and non-CRC deaths and also cause-specific deaths where there was a difference between positive and negative rates and sufficient numbers of individuals in the groups for such analysis. The outcomes were compared for positive and negative test results in both univariable and multivariable models. The latter were adjusted for gender, age and quintile of deprivation as defined by the Scottish Index of Multiple Deprivation ${ }^{11}$ since all of these have been shown to be associated with FOBT positivity. ${ }^{5}$ In addition, the models were adjusted for prescribing of medicines that increase the risk of bleeding, since this could represent a significant confounding variable. Proportional hazards were assessed using log-log plots.

All data analyses were carried out using STATA V.14 (Stata, College Station, Texas, USA).

\section{RESULTS}

There were 134192 individuals who had participated in the Scottish Pilot or Programme in Tayside during the study period. Of

Table 3 Logistic regression of the association between demographic variables and medicine prescribing (as the outcome)

\begin{tabular}{ll}
\hline & Odds ratio $(95 \% \mathrm{Cl}), \mathrm{P}$ values \\
\hline Medicines that can cause bleeding & \\
\hline Age (+1 year) & $1.082(1.080$ to 1.084$),<0.0001$ \\
\hline Males vs females & $1.08(1.05$ to 1.11$),<0.0001$ \\
\hline $\begin{array}{l}\text { Deprivation (increasing quintiles) } \\
\text { Aspirin }\end{array}$ & $1.46(1.42$ to 1.50$),<0.0001$ \\
\hline Age (+1 year) & $1.092(1.090$ to 1.094$),<0.0001$ \\
\hline Males vs females & $1.67(1.62$ to 1.72$),<0.0001$ \\
\hline Deprivation & $1.28(1.24$ to 1.32$),<0.0001$ \\
\hline
\end{tabular}

these, 271 were excluded from the study since they had no valid test result (120 had returned an incomplete test kit and $151 \mathrm{had}$ a kit that had expired). Of the remaining 133 921, there were 131207 with a negative test result and 2714 (2.03\%) with a positive test result. The demographic characteristics of the cohort (table 2) show that males were more likely to have a positive test result than females and positivity increased with increasing age and increasing deprivation. They also demonstrate an increased likelihood of a positive test result in those prescribed aspirin or any medicine that increases risk of bleeding. Premature death was increased in those with a positive test result.

Logistic regression of the association between medicine prescribing and the other demographic variables demonstrated that prescribing of both aspirin alone and all medicines associated with an increased risk of bleeding was more likely in males, older people and in areas of deprivation (table 3 ).

Figures 1, 2 and 3 show the cumulative mortality from CRC, all causes and non-CRC causes of death respectively for the negative and positive test result groups. For CRC, as would be expected, those with a positive test result had higher mortality but, for both all-cause and all non-CRC deaths, those with a positive test result also had a higher mortality compared with those with a negative test result.

The log-log plots showed no significant deviation from the proportional hazards assumption for the Cox regression analysis. In the univariable analysis, a positive test result increased the likelihood of death from CRC and of death from all causes, all cancer causes excluding CRC and all the other more specific causes of death examined (table 4). There were small numbers for external causes, blood and endocrine disease and 'other' causes, but the results of the multivariable analyses are reported for completeness. It is interesting that, for external causes, which is made up largely of trauma, the relationship between a positive 


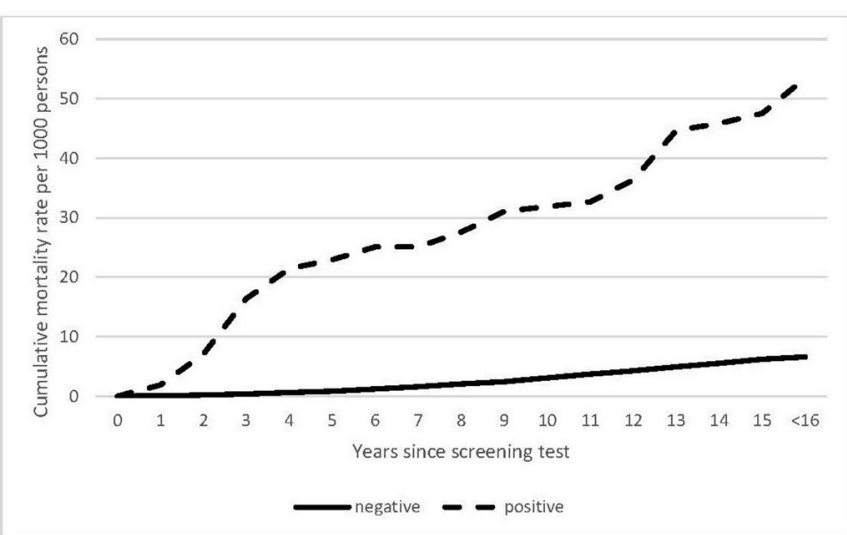

Figure 1 Cumulative colorectal cancer mortality rate per 1000 persons by gFOBT result. The more erratic shape of the 'positive' curve in comparison to figure 2 can be explained by smaller numbers. gFOBT, guaiac faecal occult blood test.

test result and external factors as a cause of death did not remain significant when adjusted for gender, age and deprivation, indicating that, not surprisingly, the association between mortality and test result was driven by these factors.

For all other cases, although the impact of a positive test result lessened slightly by adjusting for gender, age, deprivation and medicine prescribing, clear, statistically significant associations between the test result and mortality remained (table 4).

\section{DISCUSSION}

In this study, since gFOBT are qualitative tests that do not quantitate $\mathrm{f}-\mathrm{Hb}$, the effect of an incremental increase in $\mathrm{f}-\mathrm{Hb}$ concentration on colorectal (CRC) or non-CRC mortality could not be explored in detail. However, gFOBT, which are based on a peroxidase reaction that indicates the presence of the haem moiety of $\mathrm{Hb}$ in faeces, become positive at a $\mathrm{f}-\mathrm{Hb}$ concentration of around $80 \mu \mathrm{g} \mathrm{Hb} / \mathrm{g}$ faeces. ${ }^{12}$ Previous work using quantitative FIT has indicated that around $60 \%$ of the Scottish population have detectable $\mathrm{f}-\mathrm{Hb},{ }^{13}$ but only $2.03 \%$ of the study group had a positive gFOBT. Thus, by dividing the population into positive and negative test result groups using gFOBT, the positive group represents the high end of the $\mathrm{f}-\mathrm{Hb}$ spectrum found in our population, very closely equating to the highest concentration examined in the Taiwanese study $(90 \mu \mathrm{g} \mathrm{Hb} / \mathrm{g}$ faeces). When the Taiwanese data, at this cut-off $\mathrm{f}-\mathrm{Hb}$ concentration, are compared with the Scottish data, the similarities in the cumulative mortality curves for both CRC and all causes (figures 1 and 2) are striking, indicating that the observed phenomena are transferrable across continents. Given that FIT is specific for human globin, it also indicates that the findings reported here are related to $\mathrm{f}-\mathrm{Hb}$ and not to some other cause of peroxidase activity detected by the guaiac reaction.

The strong association between high $\mathrm{f}-\mathrm{Hb}$ concentrations and CRC death is not surprising since the screening test positive group represents a relatively small cohort who are at high risk of having or developing CRC (about 10 times that of the background population) ${ }^{14}$ and not all screen-detected cancer is early stage. In addition, only around $85 \%$ of the gFOBT-positive individuals underwent colonoscopy so that there was potential for CRC to have progressed in this group. ${ }^{8}$ The more interesting finding is the association with non-CRC mortality and, in contrast to the Taiwanese study, we were able
Table 4 Cox regression of the association of gFOBT result with causes of death adjusted for gender, age, deprivation and medicine prescribing

\begin{tabular}{|c|c|c|c|}
\hline & \multicolumn{2}{|l|}{ Negative } & \multirow[b]{2}{*}{ Positive } \\
\hline & HR $(95 \% \mathrm{Cl})$ & $P$ values & \\
\hline \multicolumn{4}{|l|}{ 4A. Outcome is CRC cancer mortality } \\
\hline $\begin{array}{l}\mathrm{N} \text { (mortality rate per } 1000 \text { person } \\
\text { years) }\end{array}$ & $431(0.35)$ & & $84(3.42)$ \\
\hline $\begin{array}{l}\text { Model } 1 \text { (univariable positive vs } \\
\text { negative result) }\end{array}$ & $10.0(7.94$ to 12.7$)$ & $<0.0001$ & \\
\hline $\begin{array}{l}\text { Model } 2 \text { (positive vs negative } \\
\text { result, adjusted for gender, age } \\
\text { and SIMD) }\end{array}$ & 7.76 (6.11 to 9.84$)$ & $<0.0001$ & \\
\hline $\begin{array}{l}\text { Model } 3 \text { (as model } \\
2+\text { adjusted for prescribing for } \\
\text { aspirin) }\end{array}$ & 7.76 (6.12 to 9.85$)$ & $<0.0001$ & \\
\hline $\begin{array}{l}\text { Model } 4 \text { (as model } \\
\text { 2+adjusted for prescribing } \\
\text { for medicines that can cause } \\
\text { bleeding) }\end{array}$ & 7.79 (6.13 to 9.89$)$ & $<0.0001$ & \\
\hline \multicolumn{4}{|l|}{ 4B. Outcome is all-cause mortality } \\
\hline $\begin{array}{l}\mathrm{N} \text { (mortality rate per } 1000 \text { person } \\
\text { years) }\end{array}$ & $12630(10.12)$ & & $594(24.25)$ \\
\hline $\begin{array}{l}\text { Model } 1 \text { (univariable positive vs } \\
\text { negative result) }\end{array}$ & 2.43 (2.23 to 2.63$)$ & $<0.0001$ & \\
\hline $\begin{array}{l}\text { Model } 2 \text { (positive vs negative } \\
\text { result, adjusted for gender, age } \\
\text { and SIMD) }\end{array}$ & 1.80 (1.66 to 1.96$)$ & $<0.0001$ & \\
\hline $\begin{array}{l}\text { Model } 3 \text { (as model } \\
\text { 2+adjusted for prescribing for } \\
\text { aspirin) }\end{array}$ & 1.80 (1.66 to 1.96$)$ & $<0.0001$ & \\
\hline $\begin{array}{l}\text { Model } 4 \text { (as model } \\
2+\text { adjusted for prescribing } \\
\text { for medicines that can cause } \\
\text { bleeding) }\end{array}$ & $1.76(1.62$ to 1.91$)$ & $<0.0001$ & \\
\hline \multicolumn{4}{|c|}{ 4C. Outcome is all-cause mortality excluding CRC } \\
\hline $\begin{array}{l}\mathrm{N} \text { (mortality rate per } 1000 \text { person } \\
\text { years) }\end{array}$ & $12199(9.80)$ & & $510(21.20)$ \\
\hline $\begin{array}{l}\text { Model } 1 \text { (univariable positive vs } \\
\text { negative result) }\end{array}$ & 2.18 (1.99 to 2.39$)$ & $<0.0001$ & \\
\hline $\begin{array}{l}\text { Model } 2 \text { (positive vs negative } \\
\text { result, adjusted for gender, age } \\
\text { and SIMD) }\end{array}$ & 1.63 (1.49 to 1.78$)$ & $<0.0001$ & \\
\hline $\begin{array}{l}\text { Model } 3 \text { (as model } \\
2+\text { adjusted for prescribing for } \\
\text { aspirin) }\end{array}$ & 1.62 (1.49 to 1.78$)$ & $<0.0001$ & \\
\hline $\begin{array}{l}\text { Model } 4 \text { (as model } \\
2 \text { +adjusted for prescribing } \\
\text { for medicines that can cause } \\
\text { bleeding) }\end{array}$ & $1.58(1.45$ to 1.73$)$ & $<0.0001$ & \\
\hline \multicolumn{4}{|c|}{ 4D. Outcome is all circulatory disease mortality } \\
\hline $\begin{array}{l}\mathrm{N} \text { (mortality rate per } 1000 \text { person } \\
\text { years) }\end{array}$ & $3430(2.75)$ & & $128(5.23)$ \\
\hline $\begin{array}{l}\text { Model } 1 \text { (univariable positive vs } \\
\text { negative result) }\end{array}$ & 1.92 (1.61 to 2.29$)$ & $<0.0001$ & \\
\hline $\begin{array}{l}\text { Model } 2 \text { (positive vs negative } \\
\text { result, adjusted for gender, age } \\
\text { and SIMD) }\end{array}$ & $1.33(1.12$ to 1.59$)$ & 0.002 & \\
\hline $\begin{array}{l}\text { Model } 3 \text { (as model } \\
2+\text { adjusted for prescribing for } \\
\text { aspirin) }\end{array}$ & 1.33 (1.11 to 1.59$)$ & 0.002 & \\
\hline $\begin{array}{l}\text { Model } 4 \text { (as model } \\
2 \text { +adjusted for prescribing } \\
\text { for medicines that can cause } \\
\text { bleeding) }\end{array}$ & $1.28(1.07$ to 1.53$)$ & 0.007 & \\
\hline
\end{tabular}

Continued 


\begin{tabular}{|c|c|c|c|}
\hline & \multicolumn{2}{|l|}{ Negative } & \multirow[b]{2}{*}{ Positive } \\
\hline & HR $(95 \% \mathrm{Cl})$ & $P$ values & \\
\hline \multicolumn{4}{|c|}{$4 \mathrm{E}$. Outcome is respiratory disease mortality } \\
\hline $\begin{array}{l}\mathrm{N} \text { (mortality rate per } 1000 \text { person } \\
\text { years) }\end{array}$ & $1238(0.99)$ & & $68(2.78)$ \\
\hline $\begin{array}{l}\text { Model } 1 \text { (univariable positive vs } \\
\text { negative result) }\end{array}$ & 2.85 (2.23 to 3.63$)$ & $<0.0001$ & \\
\hline $\begin{array}{l}\text { Model } 2 \text { (positive vs negative } \\
\text { result, adjusted for gender, age } \\
\text { and SIMD) }\end{array}$ & 2.02 (1.58 to 2.59$)$ & $<0.0001$ & \\
\hline $\begin{array}{l}\text { Model } 3 \text { (as model } \\
2+\text { adjusted for prescribing for } \\
\text { aspirin) }\end{array}$ & 2.02 (1.58 to 2.58$)$ & $<0.0001$ & \\
\hline $\begin{array}{l}\text { Model } 4 \text { (as model } \\
2 \text { +adjusted for prescribing } \\
\text { for medicines that can cause } \\
\text { bleeding) }\end{array}$ & 1.96 (1.53 to 2.51$)$ & $<0.0001$ & \\
\hline \multicolumn{4}{|c|}{ 4F. Outcome is digestive disease mortality } \\
\hline $\begin{array}{l}\mathrm{N} \text { (mortality rate per } 1000 \text { person } \\
\text { years) }\end{array}$ & $554(0.44)$ & & $49(2.00)$ \\
\hline $\begin{array}{l}\text { Model } 1 \text { (univariable positive vs } \\
\text { negative result) }\end{array}$ & 4.56 (3.40 to 6.10$)$ & $<0.0001$ & \\
\hline $\begin{array}{l}\text { Model } 2 \text { (positive vs negative } \\
\text { result, adjusted for gender, age } \\
\text { and SIMD) }\end{array}$ & 3.46 (2.58 to 4.64$)$ & $<0.0001$ & \\
\hline $\begin{array}{l}\text { Model 3(as model } \\
\text { 2+adjusted for prescribing for } \\
\text { aspirin) }\end{array}$ & 3.46 (2.58 to 4.64$)$ & $<0.0001$ & \\
\hline $\begin{array}{l}\text { Model } 4 \text { (as model } \\
2 \text { +adjusted for prescribing } \\
\text { for medicines that can cause } \\
\text { bleeding) }\end{array}$ & $3.36(2.50$ to 4.51$)$ & $<0.0001$ & \\
\hline \multicolumn{4}{|c|}{ 4G. Outcome is mortality from neuropsychological conditions } \\
\hline $\begin{array}{l}\mathrm{N} \text { (mortality rate per } 1000 \text { person } \\
\text { years) }\end{array}$ & $864(0.69)$ & & $37(1.51)$ \\
\hline $\begin{array}{l}\text { Model } 1 \text { (univariable positive vs } \\
\text { negative result) }\end{array}$ & 2.23 (1.60 to 3.09$)$ & $<0.0001$ & \\
\hline $\begin{array}{l}\text { Model } 2 \text { (positive vs negative } \\
\text { result, adjusted for gender, age } \\
\text { and SIMD) }\end{array}$ & 1.68 (1.20 to 2.34$)$ & 0.003 & \\
\hline Model 3 (as model & 1.67 (1.20 to 2.34$)$ & & \\
\hline $\begin{array}{l}2+\text { adjusted for prescribing for } \\
\text { aspirin) }\end{array}$ & 0.003 & & \\
\hline $\begin{array}{l}\text { Model } 4 \text { (as model } \\
2 \text { +adjusted for prescribing } \\
\text { for medicines that can cause } \\
\text { bleeding) }\end{array}$ & 1.66 (1.19 to 2.32$)$ & 0.003 & \\
\hline \multicolumn{4}{|c|}{$\begin{array}{l}\text { 4H. Outcome is mortality from external factors. Note: in this case, the relationship } \\
\text { between a positive test result and external factors as a cause of death did not remain } \\
\text { significant when adjusted for gender, age and deprivation }\end{array}$} \\
\hline $\begin{array}{l}\mathrm{N} \text { (mortality rate per } 1000 \text { person } \\
\text { years) }\end{array}$ & $309(0.35)$ & & $15(0.61)$ \\
\hline $\begin{array}{l}\text { Model } 1 \text { (univariable positive vs } \\
\text { negative result) }\end{array}$ & $2.48(1.48$ to 4.17$)$ & 0.004 & \\
\hline $\begin{array}{l}\text { Model } 2 \text { (positive vs negative } \\
\text { result, adjusted for gender, age } \\
\text { and SIMD) }\end{array}$ & $1.68(0.964$ to 2.93$)$ & 0.067 & \\
\hline \multicolumn{4}{|c|}{ 4l. Outcome is blood and endocrine disease mortality } \\
\hline $\begin{array}{l}\mathrm{N} \text { (mortality rate per } 1000 \text { person } \\
\text { years) }\end{array}$ & $308(0.25)$ & & $17(0.69)$ \\
\hline $\begin{array}{l}\text { Model } 1 \text { (univariable positive vs } \\
\text { negative result) }\end{array}$ & $2.86(1.75$ to 4.65$)$ & $<0.0001$ & \\
\hline
\end{tabular}

Continued
Table 4 Continued

\begin{tabular}{|c|c|c|c|}
\hline & \multicolumn{2}{|l|}{ Negative } & \multirow[b]{2}{*}{ Positive } \\
\hline & $\mathrm{HR}(95 \% \mathrm{Cl})$ & $P$ values & \\
\hline $\begin{array}{l}\text { Model } 2 \text { (positive vs negative } \\
\text { result, adjusted for gender, age } \\
\text { and SIMD) }\end{array}$ & 2.15 (1.32 to 3.51$)$ & 0.002 & \\
\hline $\begin{array}{l}\text { Model } 3 \text { (as model } \\
2+\text { adjusted for prescribing for } \\
\text { aspirin) }\end{array}$ & 2.15 (1.31 to 3.51$)$ & 0.002 & \\
\hline $\begin{array}{l}\text { Model } 4 \text { (as model } \\
\text { 2+adjusted for prescribing for } \\
\text { drugs that can cause bleeding) }\end{array}$ & 2.06 (1.26 to 3.36$)$ & 0.004 & \\
\hline \multicolumn{4}{|l|}{ 4J. Outcome is non-CRC mortality } \\
\hline $\begin{array}{l}\mathrm{N} \text { (mortality rate per } 1000 \text { person } \\
\text { years) }\end{array}$ & $5040(4.03)$ & & $176(7.19)$ \\
\hline $\begin{array}{l}\text { Model } 1 \text { (univariable positive vs } \\
\text { negative result) }\end{array}$ & 1.80 (1.54 to 2.09$)$ & $<0.0001$ & \\
\hline $\begin{array}{l}\text { Model } 2 \text { (positive vs negative } \\
\text { result, adjusted for gender, age } \\
\text { and SIMD) }\end{array}$ & 1.41 (1.21 to 1.65$)$ & $<0.0001$ & \\
\hline $\begin{array}{l}\text { Model } 3 \text { (as model } \\
2+\text { adjusted for prescribing for } \\
\text { aspirin) }\end{array}$ & 1.41 (1.22 to 1.65$)$ & $<0.0001$ & \\
\hline $\begin{array}{l}\text { Model } 4 \text { (as model } \\
2 \text { +adjusted for prescribing } \\
\text { for medicines that can cause } \\
\text { bleeding) }\end{array}$ & 1.40 (1.20 to 1.63$)$ & $<0.0001$ & \\
\hline \multicolumn{4}{|c|}{ 4K. Outcome is mortality from 'other' cause } \\
\hline $\begin{array}{l}\mathrm{N} \text { (mortality rate per } 1000 \text { person } \\
\text { years) }\end{array}$ & $422(0.34)$ & & $20(0.82)$ \\
\hline $\begin{array}{l}\text { Model } 1 \text { (univariable positive vs } \\
\text { negative result) }\end{array}$ & 2.45 (1.57 to 3.84$)$ & $<0.0001$ & \\
\hline $\begin{array}{l}\text { Model } 2 \text { (positive vs negative } \\
\text { result, adjusted for gender, age } \\
\text { and SIMD) }\end{array}$ & 1.76 (1.11 to 2.79$)$ & 0.02 & \\
\hline $\begin{array}{l}\text { Model } 3 \text { (as model } \\
2+\text { adjusted for prescribing for } \\
\text { aspirin) }\end{array}$ & 1.76 (1.11 to 2.79$)$ & 0.02 & \\
\hline $\begin{array}{l}\text { Model } 4 \text { (as model } \\
\text { 2+adjusted for prescribing } \\
\text { for medicines that can cause } \\
\text { bleeding) }\end{array}$ & 1.69 (1.07 to 2.69$)$ & 0.03 & \\
\hline
\end{tabular}

Results are expressed as HR derived from mortality rates (per 1000 person years) by test result.

CRC, colorectal cancer; gFOBT, guaiac faecal occult blood test; SIMD, Scottish Index of Multiple Deprivation.

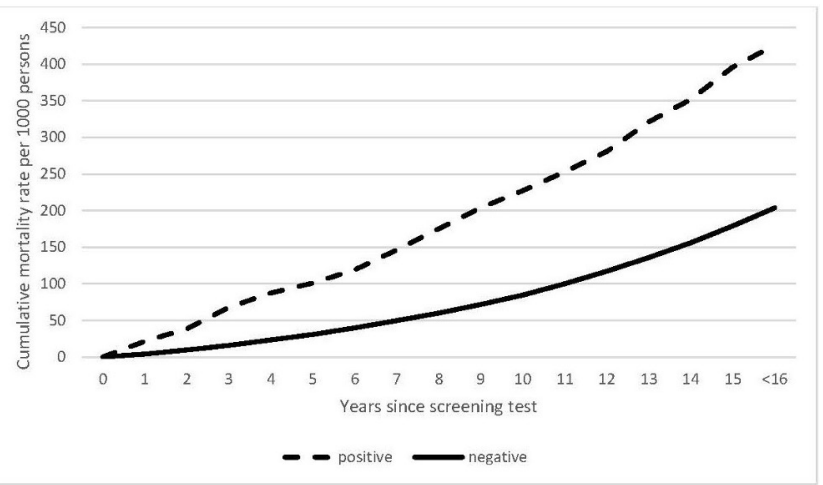

Figure 2 Cumulative all-cause mortality rate per 1000 persons by gFOBT result. gFOBT, guaiac faecal occult blood test. 


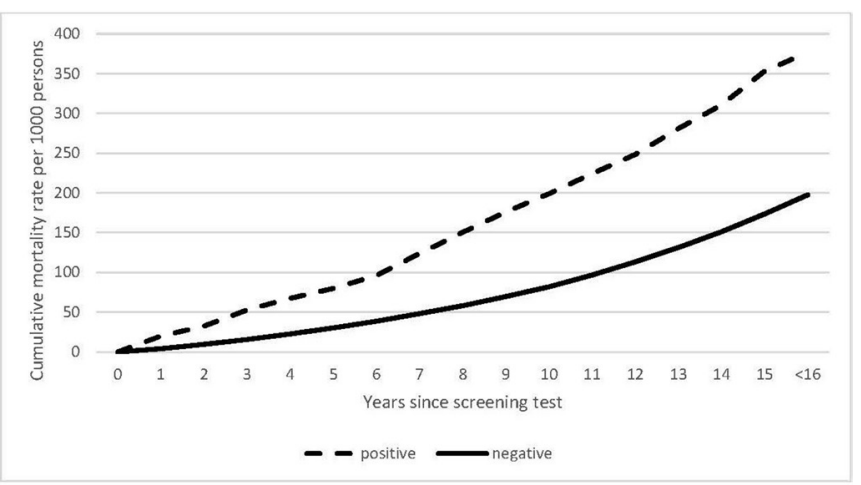

Figure 3 Cumulative all-cause (excluding CRC) mortality rate per 1000 persons by gFOBT result. CRC, colorectal cancer; gFOBT, guaiac faecal occult blood test.

to examine this association broken down by disease categories and adjusted for confounding factors.

It is clear from this study that, in the Scottish population, the presence of $\mathrm{Hb}$ in the faeces as detected by gFOBT is associated with a number of non-CRC causes of death. Some of these may be associated with an increased risk of bleeding into the gastrointestinal tract, notably 'other digestive diseases', but others, however, are not. It is of particular interest that deaths from circulatory diseases, respiratory diseases and neuropsychological disorders were associated with the presence of $\mathrm{Hb}$ in faeces and, although some non-CRC cancers may bleed into the gut, for example, stomach and pancreatic cancers, most do not.

It is noteworthy that increased $\mathrm{f}-\mathrm{Hb}$ is associated with increased male gender, age and deprivation, ${ }^{5}$ all of which are risk factors for increased all-cause mortality, but even after correcting for these factors, the presence of $\mathrm{f}-\mathrm{Hb}$ retained a strong association with common causes of premature death. In addition, although increased $\mathrm{f}-\mathrm{Hb}$ cannot be a cause of death, it may reflect the reason why male gender, age and deprivation are such strong risk factors.

Another explanation for this observation might be that people at risk of dying from circulatory disease are more likely to be taking aspirin or other medicines such as antiplatelet agents that could cause gastrointestinal bleeding than the general population and certainly our data demonstrate that these are more often taken by the male, older and more deprived populations. However, correcting for prescribed aspirin and all medicines that could cause bleeding had little effect on the association between a positive gFOBT and death from non-CRC causes.

It is also pertinent that there is convincing evidence of aspirin reducing the risk of dying from several common cancers, including CRC, ${ }^{15}$ so that aspirin usage would be unlikely explain the association of faecal haemoglobin with cancer death. This is confirmed in a study from the English Bowel Cancer Screening Programme where, among individuals undergoing colonoscopy following a positive gFOBT result, current aspirin use was associated with a lower incidence of colorectal neoplasia, possibly due to the chemopreventative effect of aspirin. ${ }^{16}$ Interestingly, a recent study has shown that aspirin does not modify the diagnostic accuracy of FIT for CRC and/or advanced colorectal neoplasia in patients with gastrointestinal symptoms. ${ }^{17}$

Thus, it would appear that the association between haemoglobin in faeces and premature non-CRC death cannot be explained simply by its association with obvious confounding factors. An alternative hypothesis invokes a generalised inflammatory state manifested by subclinical colonic inflammation and consequent occult bleeding. It is well recognised that the 'normal' colon contains inflammatory cells in the submucosa, reflecting its constant need to eliminate organisms that breach the epithelium, ${ }^{18}$ and it is likely that there is a spectrum of colonic inflammation across the asymptomatic population. It is long been assumed that colonic adenomas are detected by gFOBT screening because they bleed but, in contrast to invasive cancer, it is rare to see overt bleeding from adenomas at colonoscopy with currently available endoscopic techniques. Therefore, it may be that the increased risk of colonic adenoma in the gFOBT positive population is due to generalised colonic inflammation rather than bleeding from the adenomas themselves. This concept is supported by recent work on mucosal healing in inflammatory bowel disease, in which $\mathrm{f}-\mathrm{Hb}$ has been found to be a better marker than the more traditional measure of gut inflammation, faecal calprotectin. ${ }^{19} 20$

Inflammation as a driver of non-inflammatory disease is well recognised. There is good evidence, for example, that the majority of solid tumours arise against a background of chronic inflammation. ${ }^{21} 22$ It is also well established that systemic inflammation is a risk factor for Alzheimer's disease. ${ }^{23}$ In addition, factors predisposing to ill health, such as obesity, ${ }^{24}{ }^{25}$ sedentary behaviour, ${ }^{26}{ }^{27}$ smoking, ${ }^{28}$ alcohol dependence ${ }^{29}$ and a Western $\operatorname{diet}^{3031}$ have been shown to be associated with systemic inflammation. Exactly how these factors might lead to increased inflammation in the gastrointestinal tract remains speculative, but there are some clues in the literature. For example, adipose tissue is now recognised as a highly immunologically active organ and chronic overnutrition induces marked imbalance in the immunological network that causes local inflammation. This, in turn, releases immune mediators into the systemic circulation with inflammatory consequences for distant organs. ${ }^{24}$ In addition, physical activity has been shown to lead to increased concentrations of skeletal muscle derived IL-6 in the systemic circulation, which triggers changes in circulating levels of several other immune mediators that reduce levels of inflammation. ${ }^{26} \mathrm{It}$ is therefore not surprising that studies of systemic inflammation have demonstrated a clear correlation with all-cause mortality. ${ }^{32}$

The colonic microbiome could also play a role in this context. It is becoming increasingly clear that ulcerative colitis (UC) is associated with a characteristic bacterial spectrum in both the luminal and mucosal compartments of the colon, but that there is significant overlap between patients with UC and apparently normal control subjects. ${ }^{33}$ Thus, it is possible that some people who do not exhibit the diagnostic criteria of UC, which include frank colonic mucosal bleeding, could have a sufficient degree of colonic mucosal inflammation for them to have detectable $\mathrm{f}-\mathrm{Hb}$. Interestingly, there is now good evidence that patients with inflammatory bowel disease have a higher risk of ischaemic heart disease than normal individuals and it has been hypothesised that an impaired intestinal barrier function (or 'leaky gut') could lead to enteric bacterial translocation and/or cytokine production that could, in turn, contribute to the development of both atherosclerosis and heart failure. ${ }^{34}$ On the other hand, it is possible that microcirculatory changes in the gut associated with myocardial dysfunction could disrupt the intestinal barrier. ${ }^{34}$ Either way, there are reasons to suppose that inflammatory changes in the gut accounting for a positive gFOBT result might be associated with an increased risk of death from ischaemic heart disease.

The strengths of this study are the length of follow-up, the linkage with the National Records of Scotland which hold causes of death, and the unique ability to link with prescribing data that, in Tayside, have been collected for a sufficient number of years. ${ }^{35}$ Although statutory mortality records have recognised limitations, ${ }^{3637}$ there is no reason to suppose that misclassification of the true underlying cause of death would vary in a systematic fashion 
according to the gFOBT result. The weaknesses include reliance on the gFOBT results which cannot provide the quantitative information now afforded by FIT and the fact that prescribing does not necessarily equate to adherence to medication and cannot exclude over-the-counter medicine usage. However, previous work in Tayside estimated that over $94 \%$ of aspirin tablets used are from filled prescriptions. ${ }^{38}$ Over-the-counter use of other Non-steroidal anti-inflammatory drugs might be greater, but is very likely to be sporadic and very unlikely to be used long-term to treat potentially life-threatening diseases, especially in Scotland where there are no prescription charges.

The observations described here have three possible implications. First, if $\mathrm{Hb}$ in faeces is a risk factor for all-cause death, it may have potential as a modifiable biomarker that could be used to assess the efficacy of both lifestyle and drug interventions to reduce the risk of premature mortality. Second, it might also be used to explore the underlying reasons for different patterns of mortality in different populations across the world especially as the distribution of $\mathrm{f}-\mathrm{Hb}$ concentration have been shown to vary geographically. ${ }^{39}$ Third, in gFOBT screening, the sensitivity for cancer is about $50 \%{ }^{40}$ and about half of the people with positive test results have no cancer or adenomas in the colon ${ }^{8}$ (and this proportion rises if the cut-off $\mathrm{f}-\mathrm{Hb}$ concentration used to trigger colonoscopy is lowered using FIT) ${ }^{40}$ However, a positive test result could be used alert invitees to the risk of reversible non-communicable disease regardless of the presence or absence of colorectal neoplasia.

It is true that the risk of dying from CRC with a positive gFOBT result is considerably higher than that of dying from the other conditions explored in this study. However, CRC is a potent cause of early death and a 2-3-fold increase in risk of death from conditions that follow a more protected course indicates that there is a significant burden of non-CRC disease associated with a positive test. To fully explore the significance of the presence of $\mathrm{Hb}$ in faeces, it will be necessary to carry out prospective population-based studies of $\mathrm{f}-\mathrm{Hb}$ concentration using quantitative FIT to assess its association with lifestyle (including diet), health status and medication. It will then be necessary to carry out studies to examine the hypothesis that $\mathrm{f}-\mathrm{Hb}$ concentration might be used as a meaningful index of the success of life-prolonging interventions based on, for example, diet, weight management, exercise or medication.

Acknowledgements We acknowledge the support of the Health Informatics Centre, University of Dundee for managing and supplying the anonymised data. We also acknowledge NHS Tayside who own the data.

Contributors GL performed the statistical analyses and contributed to the writing of the manuscript. CGF directed the FOBT analyses, participated in analysis of results and contributed to the writing of the manuscript. FAC directed the pathological and histological examination of lesions found at colonoscopy, participated in analysis of results and contributed to the writing of the manuscript. DHB provided data on causes of death, participated in analysis of results and contributed to the writing of the manuscript. RJCS conceived the study, prepared the first draft of the manuscript and is the guarantor for the study.

Funding Funded by the Chief Scientist Office of the Scottish Government Health Department. Project: Establishing a Bowel Screening Research Unit (Grant Ref: $\mathrm{CZH} / 6 / 4)$.

Disclaimer The funder had no role in the study design, data collection, statistical analyses, interpretation of the results or writing of the manuscript.

Competing interests CGF undertook consultancy with Immunostics Inc., Ocean, New Jersey, USA. All other authors declare no competing interests.

Patient consent Not required.

Ethics approval The study received Caldicott approval. It did not require an ethics application since the data were obtained through the Health Informatics Centre, University of Dundee, which has generic ethics approval for linkage projects.

Provenance and peer review Not commissioned; externally peer reviewed. Data sharing statement Data sharing should be discussed with Professor RJCS, corresponding author.
Open access This is an open access article distributed in accordance with the Creative Commons Attribution Non Commercial (CC BY-NC 4.0) license, which permits others to distribute, remix, adapt, build upon this work non-commercially, and license their derivative works on different terms, provided the original work is properly cited and the use is non-commercial. See: http://creativecommons.org/ licenses/by-nc/4.0/

(c) Article author(s) (or their employer(s) unless otherwise stated in the text of the article) 2018. All rights reserved. No commercial use is permitted unless otherwise expressly granted.

\section{REFERENCES}

1 http://www.cancerresearchuk.org/about-cancer/type/bowel-cancer/about/screening/ about-bowel-cancer-screening\#what (accessed 5 Mar 15).

2 Carroll MR, Seaman HE, Halloran SP. Tests and investigations for colorectal cancer screening. Clin Biochem 2014:47:921-39.

3 Grobbee EJ, Schreuders EH, Hansen BE, et al. Association between concentrations of hemoglobin determined by fecal immunochemical tests and long-term development of advanced colorectal neoplasia. Gastroenterology 2017;153:1251-9.

4 Chen LS, Yen AM, Fraser CG, et al. Impact of faecal haemoglobin concentration on colorectal cancer mortality and all-cause death. BMJ Open 2013:3:e003740.

5 Steele RJ, Kostourou I, McClements P, et al. Effect of gender, age and deprivation on key performance indicators in a FOBT-based colorectal screening programme. J Med Screen 2010;17:68-74.

6 Libby G, Brewster DH, McClements PL, et al. The impact of population-based faecal occult blood test screening on colorectal cancer mortality: a matched cohort study. $\mathrm{Br}$ J Cancer 2012:107:255-9.

7 Steele RJC, Parker R, Patnick J, et al. A demonstration pilot trial for colorectal cancer screening in the United Kingdom: a new concept in the introduction of healthcare strategies. J Med Screen 2001;8:197-203.

8 Steele RJ, McClements PL, Libby G, et al. Results from the first three rounds of the Scottish demonstration pilot of FOBT screening for colorectal cancer. Gut 2009:58:530-5.

9 .http://apps.who.int/classifications/icd10/browse/2015/en (accessed 05 Mar 15).

10 Whynes DK, Mangham CM, Balfour TW, et al. Analysis of deaths occurring within the Nottingham trial of faecal occult blood screening for colorectal cancer. Gut 2010;59:11:1088-93

11 Steele RJC, McDonald PJ, Digby J, et al. Clinical outcomes using a faecal immunochemical test for haemoglobin in a national colorectal cancer screening programme constrained by colonoscopy capacity. United Eur Gastroentertol J 2013;1:198-205

12 McDonald PJ, Strachan JA, Digby J, et al. Faecal haemoglobin concentrations by gender and age: implications for population-based screening for colorectal cancer. Clin Chem Lab Med 2011;50:935-40.

13 Hewitson P, Glasziou P, Watson E, et al. Cochrane systematic review of colorectal cancer screening using the fecal occult blood test (hemoccult): an update. Am J Gastroenterol 2008;103:1541-9.

14 Algra AM, Rothwell PM. Effects of regular aspirin on long-term cancer incidence and metastasis: a systematic comparison of evidence from observational studies versus randomised trials. Lancet Oncol 2012;13:518-27.

15 Lee TJ, Hull MA, Rajasekhar PT, et al. Aspirin users attending for NHS bowel cancer screening have less colorectal neoplasia: chemoprevention or false-positive faecal occult blood testing? Digestion 2012;85:278-81.

16 Bujanda L, Sarasqueta C, Vega P, et al. Effect of aspirin on the diagnostic accuracy of the faecal immunochemical test for colorectal advanced neoplasia. United European Gastroenterol J 2018;6:123-30.

17 Sellers RS, Morton D. The colon: from banal to brilliant. Toxicol Pathol 2014;42:67-81.

18 Takashima S, Kato J, Hiraoka S, et al. Evaluation of mucosal healing in ulcerative colitis by fecal Calprotectin vs. fecal immunochemical test. Am J Gastroenterol 2015;110:873-80.

19 Mine S, Takeshima F, Akazawa Y, et al. Correlation of fecal markers with magnifying endoscopic stratification in patients with ulcerative colitis who are in clinical remission. Digestion 2018;97:82-9.

20 Hanahan D, Weinberg RA. Hallmarks of cancer: the next generation. Cell 2011;144:646-74.

21 Aggarwal BB, Sung B, Gupta SC, eds. Inflammation and Cancer (Advances in Experimental Medicine and Biology 816): Basel: Springer, 2014.

22 Thambisetty M. Understanding mechanisms and seeking cures for Alzheimer's disease: why we must be "extraordinarily diverse". Am J Physiol Cell Physiol 2017;313:C353-C361.

23 Mraz M, Haluzik M. The role of adipose tissue immune cells in obesity and low-grade inflammation. J Endocrinol 2014;222:R113-R127.

24 Cox AJ, West NP, Cripps AW. Obesity, inflammation, and the gut microbiota. Lancet Diabetes Endocrinol 2015;3:207-15.

25 Nimmo MA, Leggate M, Viana JL, et al. The effect of physical activity on mediators of inflammation. Diabetes Obes Metab 2013;15 Suppl 3:51-60.

26 Silverman MN, Deuster PA. Biological mechanisms underlying the role of physical fitness in health and resilience. Interface Focus 2014;4:20140040. 
27 Rom 0, Avezov K, Aizenbud D, et al. Cigarette smoking and inflammation revisited. Respir Physiol Neurobiol 2013;187:5-10.

28 Ippolito JA, Curtis BJ, Choudhry MA, et al. Alcohol and immunology: Summary of the 2012 Alcohol and Immunology Research Interest Group (AIRIG) meeting. Alcohol 2013;47:589-93.

29 Huang EY, Devkota S, Moscoso D, et al. The role of diet in triggering human inflammatory disorders in the modern age. Microbes Infect 2013;15:765-74.

30 Thorburn AN, Macia L, Mackay CR. Diet, metabolites, and "western-lifestyle" inflammatory diseases. Immunity 2014;40:833-42.

31 Proctor MJ, McMillan DC, Horgan PG, et al. Systemic inflammation predicts all-cause mortality: a glasgow inflammation outcome study. PLoS One 2015;10:e0116206.

32 Lavelle A, Lennon G, O'Sullivan 0 , et al. Spatial variation of the colonic microbiota in patients with ulcerative colitis and control volunteers. Gut 2015;64:1553-61.

33 Rogler G, Rosano G. The heart and the gut. Eur Heart J 2014;35:426-30.

34 Guthrie B, Makubate B, Hernandez-Santiago V, et al. The rising tide of polypharmacy and drug-drug interactions: population database analysis 1995-2010. BMC Med 2015;13:74-83
35 Roulson J, Benbow EW, Hasleton PS. Discrepancies between clinical and autopsy diagnosis and the value of post mortem histology; a meta-analysis and review. Histopathology 2005;47:551-9.

36 Maudsley G, Williams EM. Death certification by house officers and general practitioners--practice and performance. J Public Health Med 1993;15:192-201.

37 Morant SV, McMahon AD, Cleland JG, et al. Cardiovascular prophylaxis with aspirin: costs of supply and management of upper gastrointestinal and renal toxicity. Br J Clin Pharmacol 2004;57:188-98.

38 Fraser CG, Rubeca T, Rapi S, et al. Faecal haemoglobin concentrations vary with sex and age, but data are not transferable across geography for colorectal cancer screening. Clin Chem Lab Med 2014;52:1211-6.

39 Steele RJ, McClements P, Watling C, et al. Interval cancers in a FOBT-based colorectal cancer population screening programme: implications for stage, gender and tumour site. Gut 2012;61:576-81.

40 Digby J, Fraser CG, Carey FA, et al. Interval cancers using a quantitative faecal immunochemical test (FIT) for haemoglobin when colonoscopy capacity is limited. J Med Screen 2016;23:130-4 